\title{
Color matching model of woven fabric produced by multi-color blended rotor spun wool yarn
}

\author{
DOI: $10.35530 / I T .070 .04 .1586$
}

\section{REZUMAT - ABSTRACT}

Model de asortarea culorilor țesăturilor produse cu fire multicolore de lână filate cu rotor

Firele multicolore de lână au fost filate prin tehnologia de filare cu rotor cu 3 canale și a fost studiată caracteristica de culoare a țesăturii obţinută din aceste fire. Firele cu diferite rapoarte de amestecare a culorilor sunt filate din semitorturi pure de lână roșie, galbenă și albastră și apoi țesute. Modelarea amestecului de culori pentru ţesătura obţinută, corespunzător teoriei constante duble Kubelka-Munk, a fost realizată folosind două metode distincte: metoda celor mai mici pătrate și metoda valorii relative. Modelul a fost verificat prin calcularea diferenței de culoare dintre proba de țesătură și proporția de amestecare a fibrelor colorate. Rezultatele au arătat că diferențele medii de culoare ale probelor obţinute prin modelare sunt mai mici de 1,0, folosind oricare dintre metode. Eroarea medie a raportului de amestecare a fibrelor colorate, calculată utilizând modelul prin metodele de mai sus, este de 1,77\% și, respectiv, de 2,38\%. Se poate concluziona că, în comparație cu metoda valorii relative, metoda celor mai mici pătrate este mai bună pentru modelul $K-M$, în scopul predincţiei efectului de amestecare a culorilor și pentru raportul de amestecare al probelor.

Cuvinte-cheie: teoria K-M, efect de amestecare, predincţie, diferența de culoare, raport de amestecare

\section{Color matching model of woven fabric produced by multi-color blended rotor spun wool yarn}

Multi-color blended wool yarn was spun by three-channel rotor spinning technology, and the color feature of the corresponding woven fabric was studied. Blended yarns with different color mixing ratios are spun by pure rovings of red, yellow and blue wool, and then woven as fabric. The color blending model of Kubelka-Munk double constant theory for the woven fabrics was established using two methods: least squares method and relative value method. The model was verified by calculating color difference of the fabric sample and the blending proportion of colored fiber. The results showed that mean color differences of the samples predicted by the model is less than 1.0 using either method. The average blending ratio error of the colored fibers calculated using the model by the above methods is $1.77 \%$ and $2.38 \%$, respectively. It can be obtained that compared with relative value method, the least squares method is better for $K-M$ model to predict color blending effect and the blending ratio of the samples.

Keywords: K-M theory; blending effect; prediction; color difference; blending ratio

\section{INTRODUCTION}

Rotor spun is an open-end spinning process, by condensing single fibers as fiber strand in the rotor to form a yarn. Suitable materials for spinning can be cotton, wool, short chemical fiber and long chemical fiber, which are abundant [1-2]. The wool fibers used for this process are mostly short fibers such as fibers carded in the combing process. The aim is that the raw materials can be fully utilized and economic profit of the enterprise can be raised. Generally, multicolor wool fibers are mixed by slivers in the drawing process. Recently, multi-channel rotor spinning technology is proposed by modification on the traditional rotor spun machine [3]. Color blending can be carried out during the spinning process to realize simultaneously spinning and mixing colors. Besides, this process is flexible and efficient. The color features of the color-mixed fabric are affected by type, color, blending ratio of the fibers and weaving methods. Any change of these aspects can cause color character- istic variation [4-5]. Color matching is one of the key technical problems in textile industry. The researches of color matching methods for pre-colored fiber blends have been existed for years. Several methods have been introduced to describe the color blending of pre-colored fibers, such as Kubelka-Munk theory [6-7], Friele equation [8-9] and Stearns-Noechel model [10-11]. In this study, three-channel rotor spinning technology was used to obtain color blended wool yarn, and the color property of fabric woven with such yarns was also studied. The Kubelka-Munk double constant theory is used to study fabric color property and yarn blending ratio. The results can provide a theoretical reference for development of computer color matching system for color blended wool fabric.

\section{EXPERIMENTS}

The three-channel rotor spinning process is illustrated in figure 1. Major components include a combined 
feed roller, a carding device, a rotor and a yarn winding device. The combined roller includes three feed rollers that rotate around the same axis. Each feed roller is controlled by an independent servo motor with PLC system. The feed speeds of colored fibers are independent, thus fiber blending ratio of the spun yarn can be dynamically controlled [3]. During the spinning process, the three fiber strips are fed to the opening roller through their respective feeding rollers, and the continuous and tight fiber strips are separated into sparse fiber streams by splitting to achieve the separation and orientation of the fibers. Under the action of the acceleration airflow in the fiber transport channel, it is further separated into a single fiber form and enters the rotor. Under the action of high-speed rotation of the centrifugal force of the rotor, the single fibers are collected in the groove at the bottom of the rotor. Thus through the stripping, opening, cleaning, carding, and transfer of the carding roller, fiber bundles are separated into single fibers, and then multiple slivers asynchronously feeding into the rotor spun

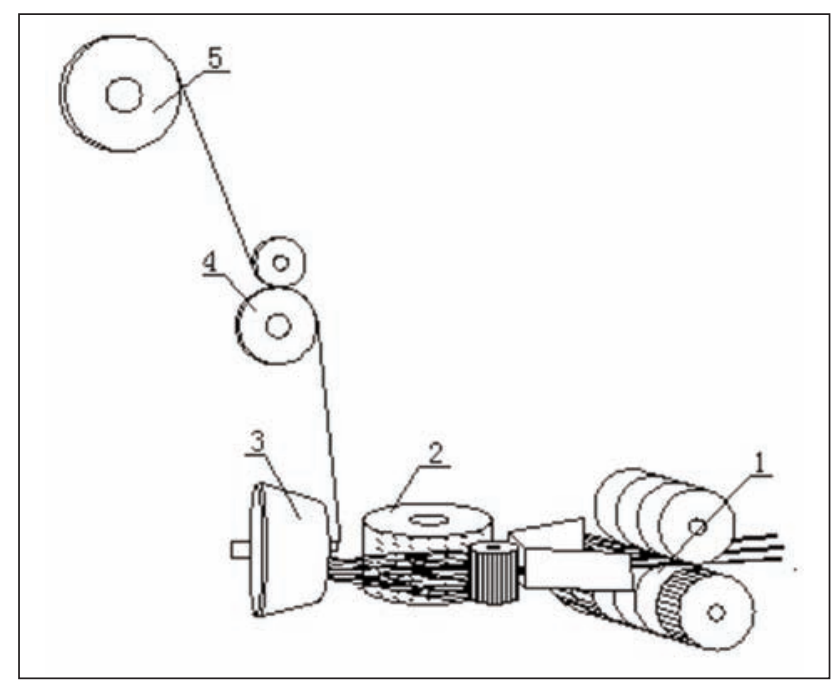

Fig. 1. Schematic diagram of the main components of multi-channel rotor spinning machine: 1 - combined feed rollers; 2 - carding roller; 3 - rotor; 4 - guide roller; 5 - yarn tube unit. Bundle is formed by multiple layers of combined condensation fibers and twisted to form a yarn by the blocking action of the false twisting disc, which is led by a mother yarn and wound into tube by winding roller.In this experiment, the rovings of red, yellow and blue wools are used as raw materials. 36 type of blended yarns are spun as listed in table 1. Yarn linear density is 44.85 Tex.

$3 / 1$ twill fabrics are woven with the color blended yarns. The warp density is $306 / 10 \mathrm{~cm}$ and the weft is $192 / 10 \mathrm{~cm}$. The woven fabric samples are shown in figure 2. 3-D mixed colors of colored fibers showed a gentler feature compared to powder mixed colors, as observed in figure 2 . These unique color scan satisfy consumers' pursuit of fashion and individuality, and provide unlimited imagination for the fashion designer. Color characteristics of fabrics were tested by Datacolor 650. It measured the spectral reflectance at a specific wavelength of the fabric, ranging from $360 \mathrm{~nm}$ to $700 \mathrm{~nm}$ at an interval of $10 \mathrm{~nm}$. During testing, the woven samples were folded 4 layers to ensure opaque and the $30 \mathrm{~mm}$ aperture was selected. In each sample, the colors at several locations were measured. The data with average color difference less than 0.2 CIELAB color unit were recorded. With the measured data, the K-M model was built.

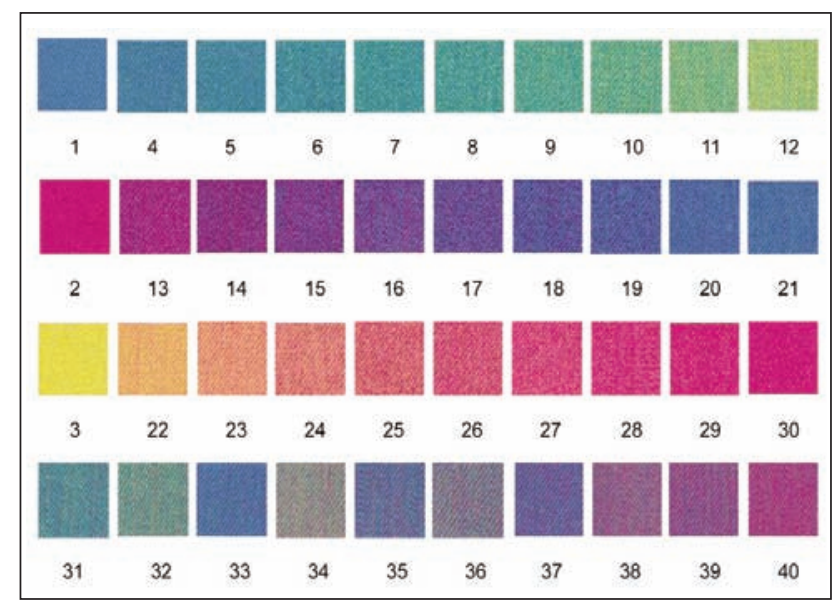

Fig. 2. Woven wool fabric with various fiber blending ratios

\begin{tabular}{|c|c|c|c|c|c|c|c|c|c|}
\hline \multicolumn{10}{|c|}{ COLOR BLEND SCHEME } \\
\hline No. & $\begin{array}{c}\text { Ratio of Red, } \\
\text { Yellow and } \\
\text { Blue }\end{array}$ & No. & $\begin{array}{c}\text { Ratio of Red, } \\
\text { Yellow and } \\
\text { Blue }\end{array}$ & No. & $\begin{array}{c}\text { Ratio of Red, } \\
\text { Yellow and } \\
\text { Blue }\end{array}$ & No. & $\begin{array}{c}\text { Ratio of Red, } \\
\text { Yellow and } \\
\text { Blue }\end{array}$ & $\begin{array}{c}\text { No. } \\
\text { Ratio of Red, } \\
\text { Yellow and } \\
\text { Blue }\end{array}$ \\
\hline 1 & $0: 0: 1$ & 9 & $0: 6: 4$ & 17 & $5: 0: 5$ & 25 & $4: 6: 0$ & 33 & $2: 1: 7$ \\
\hline 2 & $1: 0: 0$ & 10 & $0: 7: 3$ & 18 & $4: 0: 6$ & 26 & $5: 5: 0$ & 34 & $2: 4: 4$ \\
\hline 3 & $0: 1: 0$ & 11 & $0: 8: 2$ & 19 & $3: 0: 7$ & 27 & $6: 4: 0$ & 35 & $3: 2: 5$ \\
\hline 4 & $0: 1: 9$ & 12 & $0: 9: 1$ & 20 & $2: 0: 8$ & 28 & $7: 3: 0$ & 36 & $3: 4: 3$ \\
\hline 5 & $0: 2: 8$ & 13 & $9: 0: 1$ & 21 & $1: 0: 9$ & 29 & $8: 2: 0$ & 37 & $4: 1: 5$ \\
\hline 6 & $0: 3: 7$ & 14 & $8: 0: 2$ & 22 & $1: 9: 0$ & 30 & $9: 1: 0$ & 38 & $5: 3: 2$ \\
\hline 7 & $0: 4: 6$ & 15 & $7: 0: 3$ & 23 & $2: 8: 0$ & 31 & $1: 4: 5$ & 39 & $6: 2: 2$ \\
\hline 8 & $0: 5: 5$ & 16 & $6: 0: 4$ & 24 & $3: 7: 0$ & 32 & $1: 6: 3$ & 40 & $7: 2: 1$ \\
\hline
\end{tabular}




\section{K-M DOUBLE CONSTANT THEORY}

The Kubelka-Munk equation is derived from the complete radiation theory by revealing the relationship between color depth of the substrateand dyestuff concentration after the base fabric is coated with the paint [6-7]. The matched dye stuff is described by absorption coefficient and scattering coefficient, as shown in the following equation.

$$
\left(\frac{K}{S}\right)_{\lambda}=\frac{\left(1-R_{\lambda}\right)^{2}}{2 R_{\lambda}}
$$

In Equation $1, K$ is the absorption coefficient, $S$ - the scattering coefficient, $R_{\lambda}$ - the reflectivity of the sample at wave length $\lambda$.

When the Kubelka-Munk theory is used for blending effects of colored fibers, the $K / S$ value of the mixed fabric can be expressed as below.

$$
\frac{K}{S}=\frac{\sum_{i=1}^{n} C_{i} K_{i}}{\sum_{i=1}^{n} C_{i} S_{i}}
$$

In Equation 2, $i=1, \ldots, n$ is the monochromatic blending ratio, $C_{i}(i=1, \ldots, n)$ represents the proportion of the $i$-th colored fiber in the fabric, $K_{i}, S_{i}$ are the $K$ and $S$ values of each type of fibers in the fabric.

\section{Relative value method}

The relative value method is proposed by Burlone to solve the absorption coefficient and scattering coefficient of colored fibers in mixed color fabrics [12-13]. With this method, the relative value of $K$ and $S$ for a random color fiber can be obtained by using $K$ and $S$ of a specified colored fiber as a reference in the mixed color fabric. However, the true $K$ and $S$ values, representing real colors of the fibers, cannot be obtained with this method. For fabrics of two components, Equation 2 can be simplified as

$$
K / S=\frac{C_{1} K_{1}+C_{2} K_{2}}{C_{1} S_{1}+C_{2} S_{2}}
$$

Assuming $S_{1}=1, K_{1}=(K / S)_{1}$, Then

$$
\begin{aligned}
& S_{2}=\frac{C_{1}\left[(K / S) S_{1}-K_{1}\right]}{C_{2}\left[(K / S)_{2}-K / S\right]} \\
& K_{2}=(K / S)_{2} S_{2}
\end{aligned}
$$

Where: $C_{1}, C_{2}$ are the ratios of each monochromatic sample, respectively; $K_{1}, K_{2}, S_{1}, S_{2}$ are $K$ and $S$ values of the monochromatic, respectively; $(K / S)_{1}$ and $(K / S)_{2}$ are the $K / S$ value of each monochrome fabric, respectively.

\section{Least square method}

The least squares method is a set of linear independent equations proposed by Walowit.

A matrix operation is used to determine parameters of the equations so that the difference between the predicted and the true value of the dependent variable is minimal [14-16].The equations can be expressed as Equation 6:

$$
\begin{aligned}
& Y_{1}=X_{1} B_{1,1}+X_{2} B_{1,2}+X_{3} B_{1,3}+\ldots+X_{n} B_{1, n} \\
& Y_{2}=X_{1} B_{2,1}+X_{2} B_{2,2}+X_{3} B_{2,3}+\ldots+X_{n} B_{2, n} \\
& \vdots \quad \vdots \quad \vdots \quad \vdots \quad \vdots \quad \\
& Y_{m}=X_{1} B_{m, 1}+X_{2} B_{m, 2}+X_{3} B_{m, 3}+\ldots+X_{n} B_{m, n}
\end{aligned}
$$

Then Equation 6 can be converted to Equation 7 .

$\boldsymbol{Y}=\boldsymbol{B} \boldsymbol{X}$
Wherein $\boldsymbol{Y}=\left[\begin{array}{c}Y_{1} \\ Y_{2} \\ \vdots \\ Y_{m}\end{array}\right], \boldsymbol{X}=\left[\begin{array}{c}X_{1} \\ X_{2} \\ \vdots \\ X_{n}\end{array}\right], \boldsymbol{B}=\left[\begin{array}{ccc}B_{1,1} & \cdots & B_{1, n} \\ B_{2,1} & \cdots & B_{2, n} \\ \vdots & & \vdots \\ B_{m, 1} & \cdots & B_{m, n}\end{array}\right]$

According to the least squares matrix operation, the solution of the required parameter $\mathrm{X}$ can be obtained with Equation 8.

$$
\boldsymbol{X}=\left(\boldsymbol{B}^{\top} \boldsymbol{B}\right)^{-1} \boldsymbol{B}^{\top} \boldsymbol{Y}
$$

When this method is applied to K-M theory, the $K$ and $S$ values of each colored fiber in the fabric can be solved, and the color mixing ratio of each monochromatic fiber in the mixed color fabric can be obtained.

\section{Calculation of color difference}

The difference between the predicted color by the model and that of the actual sample is an important indicator for evaluating accuracy of the model. In this research, the color difference was calculated by $C M C(I: C)$ as demonstrated by Equation (9).

$$
\Delta E_{C M C}=\left[\left(\frac{\Delta L}{I S_{L}}\right)^{2}+\left(\frac{\Delta C}{c S_{C}}\right)^{2}+\left(\frac{\Delta H}{S_{H}}\right)^{2}\right]^{1 / 2}
$$

Where $I=2, c=1$.

\section{RESULTS AND DISCUSSION}

The above two methods are used to solve $K$ and $S$ of the coloredfibers in woven fabric. Kubelka-Munk double constant theory for fabrics woven by three-channel rotor spun color blending yarn also checked with the methods. In this experiment, samples No. 1-21 were used to solve the $K$ and $S$ values using the relative value method as shown in figure 3 . During the calculation, the scattering coefficient of the blue fiber was set as $1 . K$ and $S$ values of red and yellow fibers are solved by blending with blue fibers at different proportions separately. Average value of each ratio is taken as the final result. Samples 4-30 were used for the model with the least squares method to solve $K$ and $S$ as demonstrated in figure 4 . Samples No. 3140 were used to verify the color matching model.

According to the $K$ and $S$ valuescalculated by the above two methods at different wavelengths, the K/S values of fabrics woven by different colored fibers can be calculated according to Equation 2. Then reflectance of the mixed color fabric can be predicted by Equation 10.

$$
R=1+K / S-\left[(K / S)^{2}+2 \times K / S\right]^{1 / 2}
$$

According to the measured reflectivity $R$ of the verified sample and the $K$ and $S$ values of each colored 


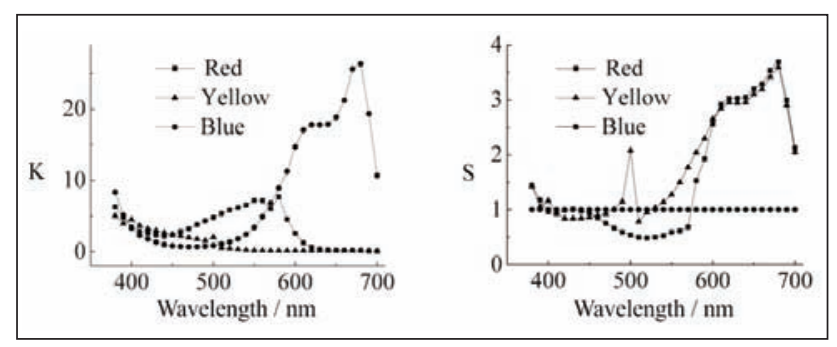

Fig. 3. $K$ and $S$ values solved by the relative value method

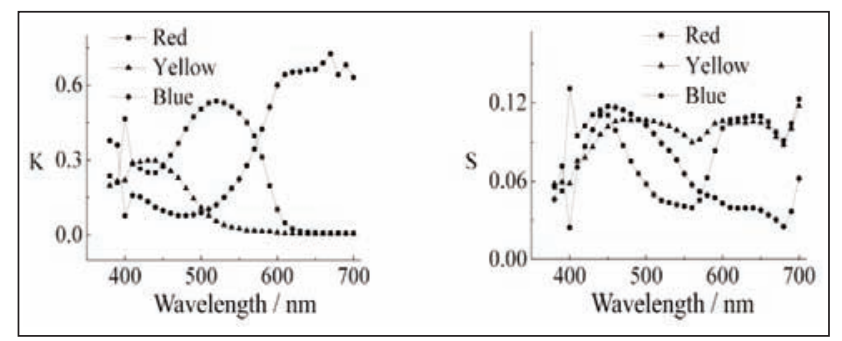

Fig. 4. $K$ and $S$ values solved by the least squares method

Table 2

\begin{tabular}{|c|c|c|c|c|c|c|c|c|}
\hline \multicolumn{9}{|c|}{ PREDICTED RESULTS OF THE MODELS } \\
\hline \multirow[b]{2}{*}{ No. } & \multicolumn{4}{|c|}{ The least squares method } & \multicolumn{4}{|c|}{ The relative value method } \\
\hline & $\begin{array}{c}\text { Color } \\
\text { difference }\end{array}$ & $\begin{array}{l}\text { Actual } \\
\text { ratios }\end{array}$ & Predicted ratios & $\begin{array}{l}\text { Ratio } \\
\text { error }\end{array}$ & $\begin{array}{c}\text { Color } \\
\text { difference }\end{array}$ & $\begin{array}{l}\text { Actual } \\
\text { ratios }\end{array}$ & Predicted ratios & $\begin{array}{l}\text { Ratio } \\
\text { error }\end{array}$ \\
\hline 31 & 0.69 & $0.1: 0.4: 0.5$ & 0.110:0.392:0.498 & $2.02 \%$ & 0.51 & $0.1: 0.4: 0.5$ & 0.109:0.392:0.499 & $1.81 \%$ \\
\hline 32 & 0.52 & 0.1:0.6:0.3 & 0.105:0.590:0.305 & $2.04 \%$ & 0.88 & 0.1:0.6:0.3 & 0.109:0.583:0.309 & $3.49 \%$ \\
\hline 33 & 0.36 & $0.2: 0.1: 0.7$ & 0.199:0.106:0.695 & $1.19 \%$ & 0.47 & 0.2:0.1:0.7 & 0.202:0.108:0.690 & $1.96 \%$ \\
\hline 34 & 0.74 & $0.2: 0.4: 0.4$ & 0.202:0.393:0.405 & $1.49 \%$ & 0.71 & 0.2:0.4:0.4 & 0.203:0.389:0.407 & $2.17 \%$ \\
\hline 35 & 0.58 & 0.3:0.2:0.5 & 0.312:0.189:0.499 & $2.38 \%$ & 0.63 & 0.3:0.2:0.5 & 0.311:0.188:0.500 & $2.32 \%$ \\
\hline 36 & 0.35 & 0.3:0.4:0.3 & 0.309:0.386:0.305 & $2.86 \%$ & 0.36 & 0.3:0.4:0.3 & 0.308:0.381:0.311 & $3.86 \%$ \\
\hline 37 & 0.58 & $0.4: 0.1: 0.5$ & 0.404:0.110:0.487 & $2.69 \%$ & 0.64 & $0.4: 0.1: 0.5$ & 0.406:0.107:0.487 & $2.65 \%$ \\
\hline 38 & 0.19 & 0.5:0.3:0.2 & 0.496:0.303:0.202 & $0.82 \%$ & 0.54 & 0.5:0.3:0.2 & 0.498:0.296:0.206 & $1.25 \%$ \\
\hline 39 & 0.16 & $0.6: 0.2: 0.2$ & 0.597:0.201:0.202 & $0.52 \%$ & 0.47 & $0.6: 0.2: 0.2$ & 0.599:0.195:0.206 & $1.25 \%$ \\
\hline 40 & 0.38 & $0.7: 0.2: 0.1$ & 0.704:0.192:0.105 & $1.70 \%$ & 0.83 & $0.7: 0.2: 0.1$ & 0.704:0.186:0.111 & $2.80 \%$ \\
\hline
\end{tabular}

fiber, the color difference between the predicted and the actual is calculated. Additionally, the blending ratio of each colored fiber in the samples is predicted by the least squares method, and the resultsare shown in the table 2.

As demonstrated by table 2, the color difference of the samplesis less than 1.0, and the average color difference is 0.46 when predicted with the least square method. The average ratio error of all verified samples is $1.77 \%$, which means the color matching results are good. The color differences of the samples predicted by the relative value method isaround 1.0 , and the average value is 0.60 . The mean value error between the predicted ratio and the actual ratio of all the verified samples is $2.36 \%$. It can be concluded that mean color difference of the samples are all less than 1.0 predicted by the models using either method. The average color differences predicted by the least squares method was 0.14 smaller than that using the relative value method, and the average ratio error was $0.59 \%$ smaller. Thus, it can be inferred that the model built by the least square method is better to predict the color and blending ratio of fabrics woven by multi-channel rotor spun color blended wool yarn.

\section{CONCLUSION}

The three-channel rotor spinning technology is used to develop color blended wool yarns. Its unique color mixing method and on-line control of color blending ratio have great advantages in production of blended yarns. The absorption coefficient $K$ and scattering coefficient $S$ of red, yellow and blue fibers are solved by relative value method and least squares method, respectively. Kubelka-Munk double constant theory for the yarn was established by the above methods. With this model, the color and fiber blending ratio can be predicted. Corrrespondingly, the color difference and blending ratio erro can becalculated. The results show that the average color difference predictedusing the model by the two methods are than 1, which satisfies color matching requirements. Compared with relative value method, the least squares method is better for K-M model to predict color blending effect and the blending ratio of the samples. Moreover, this research provided a theoretical reference for further computer intelligent color matching of fabrics woven by three-channel rotor spun color blended yarn.

\section{ACKNOWLEDGEMENT}

This work was supported by Natural Science Foundation of Jiangsu Province of China No. BK20181350, the National Natural Science Foundation of China No. 51403085, National Key R\&D Program of China (2017YFB0309200), the Fundamental Research Funds for the Central Universities No. JUSRP51631A, and Priority Academic Program Development of Jiangsu Higher Education Institutions (PAPD). 


\section{BIBLIOGRAPHY}

[1] Ahmad, Z., Eldeeb, M., Iqbal, S., et al., Effect of yarn structure on cover factor in woven fabrics, In: Industria Textila, 2018, 69, 3, pp. 197-201

[2] Yang, R. H., Xue, Y., Gao, W. D., Airflow characteristics of different groove type during rotor spinning process, In: Industria Textila, 2017, 68, 3, pp. 65-169

[3] Yang, R.H., Xue, Y., Gao, W.D., Structure and performance of color blended rotor spun yarn produced by a novel frame with asynchronous feed rollers, In: Textile Research Journal, DOI: 10.1177/ 0040517517748493

[4] Shen, J.J., Ma, H., Chen, W.G., A novel analysis of color component for top dyed melange yarn with support vector machine, In: Color Reseacher and Application, 2016, 41, 6, pp. 636-641

[5] Chae, Y., Xin, J.H., Hua, T., Color prediction models for digital Jacquard woven fabrics, In: Color Research and Application, 2016, 41, 1, pp. 64-71

[6] Davidson, H.R., Hemmendinger, H., Color prediction using the Two-Constant Turbid-Media theory, In: Journal of the Optical Society of America, 1966, 56, 8, pp. 1102-1109

[7] Allen, E., Basic equations used in computer color matching, II. Tristimulus match, two-constant theory, In: Journal of the Optical Society of America, 1974, 64, 7, pp. 991-993

[8] Philips, B., Dupont, D., Caze, C., Formulation of coloredfiber blends from Friele's theoretical model, In: Color Research and Application, 2002, 27, 3, pp. 191-198

[9] Friele, L.F.C., The application of color measurement in relation to fibre-blending, In: Journal of the Textile Institute Proceedings, 1952, 43, 8, pp. 604-611

[10] Stearns, E.I., Noechel, F., Spectrophotometric prediction of color of wool blends, In: American Dyestuff Reporter, 1944, 33, 9, pp. 177-180

[11] Yang, R.H., Han, R.Y., Lu, Y.Z., Xue, Y., Gao, W.D., Color matching of fiber blends: Stears-Noechel model of digital rotor spun yarn, In: Color Research and Application, 2018, 43, 3, pp. 415-422

[12] Burlone, D.A., Formulation of blends of precolored nylon fiber, In: Color Research and Application, 1983, 8, 2, pp. $114-120$

[13] Burlone, D.A., Effect of fibertransluceny on the color of blend of precoloredfibers, In: Textile Research Journal, 1990, 15, 3, pp. 162-167

[14] Walowit, E., An algorithm for the optimization of Kubelka-Munk absorption and scattering coefficients, In: Color Research and Application, 1987, 12, 6, pp. 340-343

[15] Amirshahi, S.H., Pailthorpe, M.T., Applying the Kubelka-Munk equation to explain the color of blends prepared from precoloredfibers. In: Textile Research Journal, 1994, 64, 6, pp. 357-364

[16] Seyam, A.F.M., Mathur, K., A general geometrical model for predicting color mixing of woven fabrics from colored warp and filling yarns, In: Fibers and Polymers, 2012, 13, 6, pp. 795-801

\section{Authors:}

RUI HUA YANG, YAYA XU, CHUN PING XIE, BO JUN XU, HONG BO WANG, WEI DONG GAO

Key Laboratory of Science \& Technology for Eco-Textiles, Education Ministry, Jiangnan University, 1800 Lihu Avenue, Wuxi, Jiangsu Province, 214122, P.R. China

e-mail of each author: yangrh@jiangnan.edu.cn, 309167947@qq.com,wxxchp@vip.163.com,wxxbj@sina.com, wxwanghb@163.com, gaowd3@163.com

\section{Corresponding author:}

RUI HUA YANG

e-mail: yangrh@jiangnan.edu.cn 